\title{
A meta-analysis of passage rate estimated by rumen evacuation with cattle and evaluation of passage rate prediction models
}

\author{
S. J. Krizsan, ${ }^{* 1}$ S. Ahvenjärvi, † and P. Huhtanen* \\ *Department of Agricultural Research for Northern Sweden, Swedish University of Agricultural Sciences, S-901 83 Umeå, Sweden \\ †MTT-Agrifood Research Finland, Animal Production Research, Fl-31600 Jokioinen, Finland
}

\begin{abstract}
A meta-analysis of studies using the flux/compartmental pool method with indigestible neutral detergent fiber (iNDF) as internal marker was conducted to study the effect of extrinsic characteristics and forage type on particle passage rate $\left(k_{p}\right)$ in cattle. Further, the $k_{p}$ prediction equations in the National Research Council (NRC) and the Cornell Net Carbohydrate and Protein System (CNCPS) were evaluated. Data comprised 172 treatment means from 49 studies conducted in Europe and the United States. In total, 145 diets were fed to dairy cows and 27 to growing cattle. A prerequisite for inclusion of an experiment was that dry matter intake, neutral detergent fiber (NDF), proportion of concentrate in the diet, body weight, and diet chemical composition were determined or could be estimated. Mixed model regression analysis including a random study effect was used to generate prediction equations of $\mathrm{k}_{\mathrm{p}}$ and to investigate the relationships between NRC and CNCPS predictions and observed $k_{p}$ of iNDF. Prediction equations were evaluated by regressing residual values on the predicted values. The best-fit model when forage type was not included was $\mathrm{k}_{\mathrm{p}}(\% / \mathrm{h})=1.19+$ $0.0879 \times \mathrm{NDF}$ intake $(\mathrm{g} / \mathrm{kg}$ of body weight $)+0.792 \times$ proportion of concentrate NDF of total NDF $+1.21 \times$ diet iNDF:NDF ratio (adjusted residual mean square error $=0.23 \% / \mathrm{h}$ ). The best general equation accounting for an effect of forage type was as follows: $k_{p}(\% / h)=F$ $+1.54+0.0866 \times \mathrm{NDF}$ intake $(\mathrm{g} / \mathrm{kg}$ of body weight) (adjusted residual mean square error $=0.21 \% / \mathrm{h}$ ), where $\mathrm{F}$ is the forage adjustment factor of the intercept. The value of $\mathrm{F}$ for grass silage, fresh grass, mixes of alfalfa and corn silage, and dry or ensiled alfalfa as sole forage component were $0.00,-0.91,+0.83$, and +0.24 , respectively. Relationships between predicted and observed $\mathrm{k}_{\mathrm{p}}$ were $\mathrm{y}=0.53( \pm 0.187)+0.41( \pm 0.0373) \times$ predicted $\mathrm{k}_{\mathrm{p}}$ and $\mathrm{y}=0.58( \pm 0.162)+0.46( \pm 0.0377) \times$ predicted $\mathrm{k}_{\mathrm{p}}$ for the NRC and CNCPS models, respectively. Re-
\end{abstract}

Received May 19, 2010.

Accepted August 23, 2010.

${ }^{1}$ Corresponding author: sophie.krizsan@njv.slu.se sidual analysis of the NRC and CNCPS models resulted in both significant mean biases (observed - predicted) of -2.40 and $-1.70 \%$ and linear biases of -0.59 and -0.53 , respectively. The results from this meta-analysis suggest that ruminal particulate matter $\mathrm{k}_{\mathrm{p}}$ is affected by forage type in the diet. Further, the evaluation of NRC and CNCPS models showed that passage rate equations developed from marker excretion curves markedly deviated from observed $k_{p}$ of iNDF derived using the rumen evacuation technique.

Key words: cattle, indigestible neutral detergent fiber, passage rate, rumen evacuation

\section{INTRODUCTION}

A ruminant animal is unique because its digestive system is based on microbial degradation in the forestomachs. The utilization of fibrous plant material is made possible by a long retention time of feed particulate matter in the rumen. Feed residues must disappear from the rumen by either digestion or passage for further intake to occur, and physical constraints can limit intake. Thus, knowledge of the factors influencing the passage rate $\left(\mathbf{k}_{\mathbf{p}}\right)$ of fiber is essential for predictions of forage utilization by ruminants. Prediction equations of $k_{p}$ are currently used in calculations of ruminal digestibility of carbohydrate and protein fractions in 1-compartment models and included in predictions of microbial efficiency (NRC, 2001; Fox et al., 2004; Danfær et al., 2006). Factors that influence particulate matter $\mathrm{k}_{\mathrm{p}}$ can be described as extrinsic or intrinsic. Characteristics of the animal and total diet are then separated from attributes describing mechanistic digesta flow through the rumen like particle size, rate of particle size reduction, and functional specific gravity (Ellis et al., 1994; Huhtanen et al., 2006). Extrinsic factors are independent of intrinsic factors and can influence the potential digestibility of a feed. Stage of maturity, proportion of leaf to stem, primary or regrowth, and forage variety/species have been suggested to be determinants of the intrinsic properties that can influence ruminal particulate matter $\mathrm{k}_{\mathrm{p}}$ in a typical cattle diet (Poppi et al., 2001; Lund, 2002; Kuoppala et al., 2009; 2010). The passage rate of 
indigestible NDF (iNDF) for diets based on corn and alfalfa silage has been higher than that predicted by an equation generated from a limited number of rumen evacuation studies (Huhtanen et al., 2006).

Prediction equations of $\mathrm{k}_{\mathrm{p}}$ have been developed based on large sets of data using rare-earths or Cr-mordanted fiber as $\mathrm{k}_{\mathrm{p}}$ markers (NRC, 2001; Seo et al., 2006). However, compartmental mean retention time estimated from the descending phase of marker excretion curves has been markedly shorter than the proportion of forestomachs to total mean retention time determined from lignin and iNDF recovery in slaughter studies (Paloheimo and Mäkelä, 1959; Walz et al., 2004; Ahvenjärvi et al., 2010). It could be hypothesized that equations generated from studies using the flux/compartmental pool method with iNDF as the internal marker would give more biologically relevant predictions. Previous prediction equations of $k_{p}$ of iNDF have been generated from studies restricted to dairy cows primarily fed grass silage-based diets (Danfær et al., 2006; Krizsan et al., 2010).

The objective with this study was to summarize findings across published studies to generate empirical prediction equations of $k_{p}$ of iNDF by conducting a meta-analysis of data from studies performed with cattle fed a range of different forages. Further, National Research Council (NRC, 2001) and Cornell Net Carbohydrate and Protein System (CNCPS; Seo et al., 2006) $k_{p}$ prediction equations were evaluated with these data.

\section{MATERIALS AND METHODS}

\section{Database Construction and Calculations}

A database was constructed from experiments with cattle where the experimental objective was to study dietary effects on digestion and passage kinetics of fiber fractions. In all trials, $\mathrm{k}_{\mathrm{p}}$ of iNDF was determined using the flux/compartmental pool method (Ellis et al., 1994):

$$
\begin{gathered}
\mathrm{k}_{\mathrm{p}}(\% / \mathrm{h})=100 \times \text { flux of indigestible component } \\
\text { into the compartment }(\mathrm{kg} / \mathrm{h}) / \text { rumen pool } \\
\text { of indigestible component }(\mathrm{kg}) .
\end{gathered}
$$

A total of 49 studies, using ruminally cannulated animals and comprising 172 treatment means, was pooled in a database. Forty $(\mathrm{n}=145)$ of these were conducted with dairy cows and $9(\mathrm{n}=27)$ were with growing cattle. Studies included in the database were conducted in Europe and in the United States. The diets in the experiments consisted of different types of forages; fresh grass, grass hay or silage, legume, whole crop (barley and a pea-barley mix), corn, and mixtures of alfalfa and corn silages were fed at different levels of concentrate feeding. The concentrate fed with the different forages differed in amount and composition, but were offered at fixed levels or proportions throughout a study. In the database, 26 experiments were primarily targeted on forage source, 13 studies dealt with different sources or levels of concentrate supplementation, and 8 studies had factorial arrangement of treatments including both forage type and level of concentrate supplementation. One experiment used different feeding levels to induce differences in digesta kinetic parameters to study methodological aspects; another study looked primarily at feeding frequency and rumen evacuation schedule effects on digestion kinetics. The list of studies used in this meta-analysis is given in the Appendix.

The prerequisite for an experiment to be included in the analysis was that $k_{p}$ was calculated for iNDF, preferably based on flow of iNDF from intake $(\mathrm{n}=159)$ or fecal output of iNDF $(n=13)$ and rumen pool size of iNDF. The rumen evacuation technique is based on assumptions of a steady-state rumen pool size and no disturbance of the normal rumen function (Robinson et al., 1987). In the experiments included in this database, rumens were evacuated several times, except for 3 studies with single evacuations $(\mathrm{n}=10)$. Rumen iNDF pool size has shown little variation between different rumen evacuation time points equally spaced over 3 d for cattle fed twice daily (Huhtanen et al., 2007). Rumen digesta pool size was judged as representative of diurnal mean values. Concentration of iNDF in feed or feed ingredients, rumen contents, and fecal samples was determined either by long-term rumen incubations of the samples in nylon bags for a minimum of $96 \mathrm{~h}$ up to $504 \mathrm{~h}(\mathrm{n}=140)$, or by in vitro incubation in buffered rumen fluid without addition of pepsin for 120 or 240 $\mathrm{h}(\mathrm{n}=32)$. In one study, $\mathrm{k}_{\mathrm{p}}$ was determined based on the indigestible component of ADF $(n=2)$ instead of iNDF. A further prerequisite for inclusion of an experiment was that production parameters (forage and total DMI, milk production, and BW) and diet chemical composition (concentrations of $\mathrm{CP}$, NDF, ether extracts, ash, and iNDF) were determined or could be estimated. If concentrate chemical composition was not completely reported, default feed table values from the country where the experiment was performed were used. Dietary concentration of NFC for each observation was calculated as OM (\% of DM) - [CP (\% of $\mathrm{DM})+\mathrm{NDF}(\%$ of DM) + ether extracts (\% of DM)]. When silage iNDF concentrations were not reported, the estimates were back-calculated from given numbers of $k_{p}$ of iNDF according to equation [1], concentration of iNDF in concentrate, concentrate and forage DMI, 
and rumen iNDF pool size. Concentrate iNDF values were given in most experiments, but values for 2 studies $(\mathrm{n}=8)$ were estimated from ingredient composition and iNDF concentration in ingredients derived from data sets from MTT Agrifood Research Finland. Two treatments reported by Dado and Allen (1995), where inert bulk was introduced in the rumen of the cows, were not included in the database.

The NRC (2001) and CNCPS (Seo et al., 2006) give separate $k_{p}$ prediction equations for concentrate and forage feed:

$$
\begin{gathered}
\mathrm{k}_{\mathrm{p}} \text { of concentrates }(\% / \mathrm{h})=2.904+1.375 \times \mathrm{DMI} \\
(\% \text { of } \mathrm{BW})-0.020 \times \mathrm{X}_{2},
\end{gathered}
$$

$\mathrm{k}_{\mathrm{p}}$ of dry forages $(\% / \mathrm{h})=3.362+0.479 \times \mathrm{DMI}$

$$
(\% \text { of } \mathrm{BW})-0.007 \times \mathrm{X}_{2}-0.017 \times \mathrm{X}_{3},
$$

$$
\mathrm{k}_{\mathrm{p}} \text { of wet forages (silages and fresh; } \% / \mathrm{h} \text { ) = }
$$

$$
3.054+0.614 \times \text { DMI }(\% \text { of BW })
$$

and

$$
\begin{gathered}
\mathrm{k}_{\mathrm{p}} \text { of concentrates }(\% / \mathrm{h})=1.169+0.1375 \\
\times \mathrm{FpBW}+0.1721 \times \mathrm{CpBW} \\
\mathrm{k}_{\mathrm{p}} \text { of forages }(\% / \mathrm{h})=2.365+0.0214 \times \mathrm{FpBW} \\
+0.0734 \times \mathrm{CpBW}+0.069 \times \mathrm{FDMI},
\end{gathered}
$$

respectively, where $\mathrm{X}_{2}=$ percentage of concentrate in diet DM, $\mathrm{X}_{3}=$ percentage of NDF in DM, FpBW = forage DMI $(\mathrm{g} / \mathrm{kg}$ of $\mathrm{BW}), \mathrm{CpBW}=$ concentrate DMI $(\mathrm{g} / \mathrm{kg}$ of BW $)$, and FDMI = forage DMI $(\mathrm{kg} / \mathrm{d})$. Therefore, an aggregated $\mathrm{k}_{\mathrm{p}}$ was calculated using the prediction equations [2], [3], and [4] for NRC and equations $[5]$ and [6] for CNCPS as follows:

$$
\begin{gathered}
\text { Aggregated } \mathrm{k}_{\mathrm{p}}(\% / \mathrm{h})=(\text { CiNDFI }+ \text { FiNDFI }) / \\
{\left[\left(\text { CiNDFI } / \mathrm{k}_{\mathrm{p}} \text { of concentrates, } \% / \mathrm{h}\right)\right.} \\
\left.+\left(\text { FiNDFI } / \mathrm{k}_{\mathrm{p}} \text { of forages, } \% / \mathrm{h}\right)\right]
\end{gathered}
$$

where CiNDFI $=$ concentrate iNDF intake $(\mathrm{g} / \mathrm{kg}$ of $\mathrm{BW})$ and FiNDFI $=$ forage iNDF intake $(\mathrm{g} / \mathrm{kg}$ of BW). The aggregated $k_{\mathrm{p}}$ calculations in equation [7] were based primarily on concentrate and forage iNDF intake $(\mathrm{n}=165)$, but when not available concentrate and forage NDF intake were used $(n=7)$.

To evaluate if the relationships between independent variables and $\mathrm{k}_{\mathrm{p}}$ were curvilinear, the basic and most correct type of nonlinear regression in this case was transformed data regression (i.e., a natural logarithm transformation). Further, the accuracy of the best generated passage kinetic model was evaluated by comparing NDF digestibility predictions based on passage kinetic parameters with observed in vivo NDF digestibility. The passage kinetic parameters estimated by the best prediction equation generated from this database were used in a 2-compartment rumen model as described by Allen and Mertens (1988). The total mean rumen retention time $\left(1 / \mathrm{k}_{\mathrm{p}}\right)$ was divided in the ratio of 0.4:0.6 between nonescapable and escapable pools and the digestion rate of potentially digestible NDF (pdNDF) was assumed to $5.0 \% / \mathrm{h}$. Mean values for the proportion of concentrate on an NDF basis and iNDF:NDF ratio were obtained from the data set of digestibility trials in dairy cows (Huhtanen et al., 2009; Nousiainen et al., 2009) to calculate passage kinetic parameters at different NDF intakes.

\section{Statistical Analysis}

The relationships between $k_{p}$ of iNDF and independent variables were analyzed using the mixed model procedure of SAS (Littell et al., 1996). The model was $\mathrm{Y}=\mathrm{B}_{0}+\mathrm{B}_{1} \mathrm{X}_{1 \mathrm{ij}}+\mathrm{b}_{0}+\mathrm{b}_{1} \mathrm{X}_{1 \mathrm{ij}}+\mathrm{B}_{2} \mathrm{X}_{2 \mathrm{ij}}+\ldots+\mathrm{B}_{\mathrm{n}} \mathrm{X}_{\mathrm{nij}}$ $+e_{i j}$, where $B_{0}, B_{1} X_{1 i j}, B_{2} X_{2 i j} \ldots X_{n i j}$ were the fixed effects and $b_{0}, b_{1}$, and $e_{i j}$ were the random experiment effects (intercept, slope, and error), where $\mathrm{i}=1 \ldots \mathrm{n}$ studies and $j=1 \ldots n_{i}$ values. In multivariate models, only the first independent variable was treated as a random factor. The best-fit model was chosen based on the lowest residual mean square error (RMSE) and Akaike's information criterion (AIC). Akaike's information criterion indicates the model likely to be the most correct with the smallest number of parameters. In the tables, RMSE values adjusted for the random study effect are presented. Variation in the experimental units, experimental designs, different measurement methods, and laboratory assays would contribute to the random effect of study. Rationale and further details of using mixed model analysis to integrate quantitative findings from multiple studies are described by St-Pierre (2001) and Sauvant et al. (2008).

Model adequacy was controlled by generating residual values from observed minus predicted values from the mixed model regression. Mixed model regression analysis was used to test for differences in $k_{p}$ of iNDF between forage types, and between growing cattle and dairy cows. Passage rate predictions of different forage types were compared with that predicted for grass silage-based diets. The forage component of the diets was initially classified into 13 different groups: grass silage with $<550 \mathrm{~g}$ of $\mathrm{NDF} / \mathrm{kg}$ of $\mathrm{DM}(1 ; \mathrm{n}=52)$, 
Table 1. Description of the experimental animal and diet characteristics in the database for prediction and evaluation of passage rate in cattle

\begin{tabular}{|c|c|c|c|c|c|}
\hline Item & $\mathrm{n}$ & Mean & SD & Minimum & Maximum \\
\hline \multicolumn{6}{|l|}{ Intake (g/kg of BW) } \\
\hline $\mathrm{DM}$ & 172 & 29.0 & 7.93 & 8.4 & 45.6 \\
\hline $\mathrm{NDF}$ & 172 & 10.6 & 2.68 & 3.8 & 16.6 \\
\hline Forage DM & 172 & 17.7 & 5.27 & 2.9 & 32.5 \\
\hline Forage NDF & 172 & 8.6 & 2.49 & 1.5 & 16.0 \\
\hline \multicolumn{6}{|l|}{ Apparent total-tract digestibility (\%) } \\
\hline $\mathrm{OM}$ & 155 & 71.8 & 8.21 & 32.7 & 86.4 \\
\hline $\mathrm{NDF}$ & 157 & 59.7 & 12.8 & 25.0 & 86.1 \\
\hline Milk production $(\mathrm{kg} / \mathrm{d})$ & 145 & 26.1 & 8.68 & 0 & 42.5 \\
\hline BW (kg) & 172 & 574 & 87.8 & 315 & 710 \\
\hline \multicolumn{6}{|l|}{ Diet composition (\% of DM) } \\
\hline $\mathrm{NDF}$ & 172 & 38.2 & 9.32 & 18.4 & 66.1 \\
\hline $\mathrm{NFC}$ & 172 & 34.4 & 8.55 & 12.5 & 56.5 \\
\hline $\mathrm{CP}$ & 172 & 16.7 & 2.91 & 5.98 & 24.1 \\
\hline $\mathrm{iNDF}^{1}$ & 172 & 8.87 & 3.61 & 2.37 & 17.4 \\
\hline Concentrate proportion, DM basis & 172 & 0.37 & 0.182 & 0 & 0.75 \\
\hline Concentrate proportion, NDF basis & 172 & 0.20 & 0.144 & 0 & 0.60 \\
\hline Passage rate $\left(\mathrm{k}_{\mathrm{p}}\right)$ of iNDF, $\% / \mathrm{h}$ & 172 & 2.56 & 0.668 & 1.10 & 5.11 \\
\hline Aggregated $\mathrm{k}_{\mathrm{p}} \mathrm{NRC}^{2}(\% / \mathrm{h})$ & 172 & 5.01 & 0.655 & 2.95 & 6.25 \\
\hline Aggregated $\mathrm{k}_{\mathrm{p}} \mathrm{CNCPS}^{2}(\% / \mathrm{h})$ & 172 & 4.23 & 0.726 & 2.71 & 5.92 \\
\hline
\end{tabular}

grass silage with $>550 \mathrm{~g}$ of $\mathrm{NDF} / \mathrm{kg}$ of $\mathrm{DM}(2 ; \mathrm{n}=$ $20)$, legume silages $(3 ; \mathrm{n}=17)$, whole crop silage $(4$; $\mathrm{n}=6)$, whole-crop silage mixed with grass silage $(5 ; \mathrm{n}$ $=5)$, alfalfa mixed with corn silage $(6 ; \mathrm{n}=22)$, fresh grass $(7 ; \mathrm{n}=7)$, hay of grasses and legumes $(8 ; \mathrm{n}=$ $20)$, ryegrass silage $(9 ; \mathrm{n}=8)$, grass silage mixed with legumes $(10 ; \mathrm{n}=9)$, corn silage $(11 ; \mathrm{n}=3)$, wheat straw $(12 ; \mathrm{n}=3)$, and dried or ensiled alfalfa $(13 ; \mathrm{n}$ $=11)$. Forage treatments overlapped in groups 3, 8, and 13. Numbers in parentheses therefore exceeded the total number of treatment means. With no indication of differences $(P \geq 0.10)$, the observations for the forage type tested were pooled with the observations of the grass silage group.

The aggregated $k_{\mathrm{p}}$ calculated from the prediction equations of NRC (2001) and CNCPS (Seo et al., 2006) were centered by subtracting the mean of all predicted values from each prediction within each system. This transformation centered the data points to a mean value of zero. The slope and intercept estimates in the regression is thereby made orthogonal and will allow for a proper interpretation of the regression model. Residual values were calculated from observed $k_{p}$ of iNDF minus the predicted $\mathrm{k}_{\mathrm{p}}$. Prediction equations were evaluated by regressing residual values on the predicted values. Mean biases were assessed by using the intercepts of the regression equations, and the slopes of the regression equations were used to determine the presence of linear biases (St-Pierre, 2003).

\section{RESULTS}

\section{Description of the Database}

The experimental data for dairy cows and growing cattle combined are described in Table 1. Considerable variation existed in both diet composition and animal parameters. The range in DMI was much larger for dairy cows than for growing cattle (8.7 to $46.6 \mathrm{~g} / \mathrm{kg}$ of BW vs. 8.4 to $20.1 \mathrm{~g} / \mathrm{kg}$ of BW, respectively), whereas the difference in intake range between animal type was much smaller on an NDF basis (3.8 to $16.6 \mathrm{~g} / \mathrm{kg}$ of BW vs. 4.0 to $12.0 \mathrm{~g} / \mathrm{kg}$ of $\mathrm{BW}$ for dairy cows and growing cattle, respectively). Mean BW for dairy cows and growing cattle was 606 and $405 \mathrm{~kg}$, respectively. Concentration of NDF was generally lower in dairy cow diets compared with diets fed to growing cattle (36.7 vs. $46.0 \%$ of DM, respectively). This is consistent with an on-average higher proportion of concentrate fed to dairy cows than growing cattle (0.38 vs. 0.30 , respectively). Small differences were found in mean and variability of $\mathrm{k}_{\mathrm{p}}$ of iNDF between animal types in the data set (Table 1).

Intake of NDF (NDFI) was negatively related to proportion of concentrate on an NDF basis [CProp $(\mathbf{N D F})]:$ NDFI, $\mathrm{g} / \mathrm{kg}$ of $\mathrm{BW}=11.9-6.42 \times$ CProp $(\mathrm{NDF}) ; P=0.01$, adjusted RMSE $=1.00 \mathrm{~g} / \mathrm{kg}$ of BW. Forage intake on an NDF basis (FNDFI) was negatively related to concentrate intake on an NDF basis: FNDFI, $\mathrm{g} / \mathrm{kg}$ of $\mathrm{BW}=9.66-0.574 \times$ concentrate intake on 
NDF basis, $\mathrm{g} / \mathrm{kg}$ of $\mathrm{BW} ; P=0.02$, adjusted RMSE $=0.93 \mathrm{~g} / \mathrm{kg}$ of BW. Forage intake also was negatively related to CProp (NDF): FNDFI, g/ $\mathrm{kg}$ of $\mathrm{BW}=11.7$ $-15.8 \times$ CProp (NDF); $P<0.01$, adjusted RMSE $=$ $0.71 \mathrm{~g} / \mathrm{kg}$ of $\mathrm{BW}$, but only the last relationship was strong. No other univariate mixed model regressions between independent variables of biological and predictive relevance to $\mathrm{k}_{\mathrm{p}}$ displayed significant $(P \geq 0.28)$ relationships.

\section{Effect of Animal Type on Passage Rate of iNDF}

Animal type did not give any adjustment of either intercept separately $(P \geq 0.17)$ or of both intercept and slope $(P \geq 0.20)$ in univariate mixed model regressions with any of the independent variables DMI, NDFI, forage DMI, or FNDFI. Further, only NDFI as an independent variable was associated $(P=0.04)$ with $\mathrm{k}_{\mathrm{p}}$ of iNDF when animal type was included as a fixed effect in the regression equation. There were no further improvements of the prediction equation of $k_{p}$ of iNDF for growing cattle and dairy cows separately in bivariate regressions including either concentrate NDFI (expressed in $\mathrm{g} / \mathrm{kg}$ of $\mathrm{BW}$ ) or CProp (NDF) in addition to NDFI as independent variables.

\section{Regressions of Extrinsic Characteristics and Forage Type on Passage Rate of iNDF}

The effects of extrinsic diet and animal characteristics on $\mathrm{k}_{\mathrm{p}}$ in univariate and multivariate linear regressions estimated by mixed model regression analysis are presented in Table 2. All 4 independent variables in the univariate regressions of Table 2 showed a significant relationship with $\mathrm{k}_{\mathrm{p}}$ of iNDF $(P \leq 0.02)$. Intake of NDF performed slightly better as a predictor in the univariate regressions of $k_{p}$ than did the other independent variables as indicated by a low adjusted RMSE (Table 2 ). The mean response in $k_{p}$ of iNDF to increased NDFI was more than twice as high as for increased DMI (0.0760 vs. $0.0375 \% / \mathrm{h}$ per $\mathrm{g}$ intake of NDF and DM per $\mathrm{kg}$ of BW, respectively; Table 2). Neither concentrate DMI (expressed as $\mathrm{g} / \mathrm{kg}$ of BW) nor CProp on a DM basis $[\mathbf{C P r o p}(\mathbf{D M})]$ had a significant effect $(P \geq 0.60$; equations not presented) when included in bivariate models with DMI. Including CProp (NDF) in a bivariate model with NDFI did not show a significant effect on $\mathrm{k}_{\mathrm{p}}$ $(P=0.08$; Table 2$)$. However, this bivariate regression lowered AIC compared with the univariate model based on NDFI (Table 2). Segregating total intake to forage and concentrate intake on an NDF basis in bivariate models did not result in any further improvements. When adding a third variable descriptive of the chemical characteristics of the diets (concentration of NDF,
$\mathrm{NFC}$, or $\mathrm{CP}$ ) to the best bivariate regressions, none of these variables had significant effect $(P \geq 0.08)$ on $\mathrm{k}_{\mathrm{p}}$. Only the equations with dietary ratio of iNDF:NDF as a third independent variable gave significant effects of all variables on $\mathrm{k}_{\mathrm{p}}(P \leq 0.05$; Table 2$)$. There was comparable goodness of fit of 2 multivariate regressions including NDFI, CProp (NDF), and iNDF:NDF, or FNDFI, CProp (NDF), and iNDF:NDF (Table 2). The equation based on FNDFI as the first independent variable had higher standard errors of the regression coefficients for the first and second independent variable when compared with the equation based on NDFI (0.103 and 0.505 vs. 0.0879 and 0.404 , respectively). Examining plots of residuals against predicted values and residuals against the regressor NDFI, neither obvious model defects nor a nonconstant variance pattern was observed for these equations (results not presented). The density of the residuals plotted in a histogram supported the assumption of normally distributed data for both models. The curvilinear model of $k_{p}$ of iNDF, adjusted to the data with transformed data regression (i.e., a natural logarithm transformation) generated the following equation:

$$
\begin{gathered}
\mathrm{k}_{\mathrm{p}}, \% / \mathrm{h}=0.828 \times \mathrm{NDFI}^{0.373} \\
+\mathrm{e}^{(0.435 \times \mathrm{CProp}(\mathrm{NDF})+0.551 \times \mathrm{iNDF}: \mathrm{NDF})} \\
(\text { adjusted RMSE }=0.25 \% / \mathrm{h}) .
\end{gathered}
$$

The best general equation correcting for the effect of forage type was as follows: $\mathrm{k}_{\mathrm{p}}, \% / \mathrm{h}=\mathrm{F}+1.54$ $+0.0866 \times \mathrm{NDFI}, \mathrm{g} / \mathrm{kg}$ of $\mathrm{BW}$ (adjusted RMSE $=$ $0.21 \% / \mathrm{h}$ ), where $\mathrm{F}=$ forage adjustment factor of the intercept. The effect on $\mathrm{k}_{\mathrm{p}}$ of fresh grass $(P=0.02)$, mixes of alfalfa and corn silage $(P<0.01)$, and dry or ensiled alfalfa as the sole forage component $(P=0.10)$ was estimated by adjusting the intercept in the general equation accounting for forage. The adjustment factor on the intercept for grass silage, fresh grass, mixes of alfalfa and corn silage, and dry or ensiled alfalfa were $0.00,-0.91,+0.83$, and +0.24 , respectively.

\section{Evaluation of Passage Rate Models}

Both the NRC and CNCPS models overestimated ruminal passage rate (i.e., underestimated total retention time of particulate matter in the rumen). Relationships between predicted and observed $\mathrm{k}_{\mathrm{p}}$ were $\mathrm{y}=$ $0.53( \pm 0.187)+0.41( \pm 0.0373) \times$ predicted $\mathrm{k}_{\mathrm{p}}$ and $\mathrm{y}=$ $0.58( \pm 0.162)+0.46( \pm 0.0377) \times$ predicted $k_{p}$ for the NRC and CNCPS models, respectively. The evaluation of the NRC and CNCPS prediction equations of $\mathrm{k}_{\mathrm{p}}$ by regressing residual values on the predicted values are 
Table 2. Effects of extrinsic diet characteristics on passage rate of indigestible NDF (iNDF; \%/h) estimated by mixed model regression analysis $\left(\mathrm{Y}=\mathrm{A}+\mathrm{BX}_{1}+\mathrm{CX}_{2}+\mathrm{DX}_{3}\right)^{1}$

\begin{tabular}{|c|c|c|c|c|c|c|c|c|c|c|}
\hline $\mathrm{X}_{1}$ & $\mathrm{X}_{2}$ & $\mathrm{X}_{3}$ & $\mathrm{~A}^{2}$ & $\mathrm{~B}^{3}$ & $\mathrm{C}$ & $P$-value & $\mathrm{D}$ & $P$-value & $\mathrm{RMSE}^{4}$ & $\mathrm{AIC}^{5}$ \\
\hline NDFI & & & 1.77 & 0.0760 & & & & & 0.22 & 210 \\
\hline FDMI & & & 2.03 & 0.0314 & & & & & 0.23 & 219 \\
\hline NDFI & CNDFI & & 1.67 & 0.0697 & 0.0790 & 0.05 & & & 0.23 & 211 \\
\hline NDFI & CProp (NDF) & & 1.52 & 0.0861 & 0.756 & 0.08 & & & 0.23 & 207 \\
\hline FNDFI & CNDFI & & 1.77 & 0.0660 & 0.109 & $<0.01$ & & & 0.23 & 212 \\
\hline FNDFI & CProp (NDF) & iNDF:NDF & 1.07 & 0.103 & 1.73 & $<0.01$ & 1.15 & 0.01 & 0.23 & 198 \\
\hline
\end{tabular}

${ }^{1} \mathrm{DMI}$ in $\mathrm{g} / \mathrm{kg}$ of $\mathrm{BW}$; NDFI = intake of NDF in $\mathrm{g} / \mathrm{kg}$ of BW; FDMI = forage DMI in $\mathrm{g} / \mathrm{kg}$ of BW; FNDFI = forage NDFI in $\mathrm{g} / \mathrm{kg}$ of BW; CNDFI $=$ concentrate NDFI in $\mathrm{g} / \mathrm{kg}$ of BW; CProp (NDF) = concentrate proportion on NDF basis; NDF = diet NDF concentration (\% of DM); and iNDF:NDF $=$ ratio between diet iNDF and NDF concentrations.

${ }^{2} \mathrm{~A}: P \leq 0.03$.

${ }^{3} \mathrm{~B}: P \leq 0.02$.

${ }^{4} \mathrm{RMSE}=$ residual mean square error. The values are adjusted for random study effect.

${ }^{5} \mathrm{AIC}=$ Akaike's information criterion.

presented in Figure 1. Residual analysis of the NRC and CNCPS models resulted in both significant $(P<$ 0.001 ) mean biases of -2.40 and $-1.70 \% / \mathrm{h}$ and linear biases of -0.59 and -0.53 , respectively.

\section{DISCUSSION}

\section{Effect of Animal Type on Predictions of Ruminal Particulate Matter Passage Rate}

This database used data on growing cattle, and dry and lactating dairy cows. Using pooled data of cattle in this evaluation of the effect of animal and feed variables on $k_{p}$ of iNDF was justified from statistical testing of animal type in mixed model regressions. In these data, large differences were observed in the range of DMI, but not in NDFI (both in $\mathrm{g} / \mathrm{kg}$ of BW) between dairy cows and growing cattle. Pooled cattle data were also used in the development of empirical prediction equations of $k_{p}$ in NRC (2001) and CNCPS (Seo et al., 2006). However, Cannas (2002) compared predictions of $\mathrm{k}_{\mathrm{p}}$ from the CNCPS model developed for cattle with observed $k_{p}$ in sheep and found that the predictions underestimated the ruminal passage of feed particles in sheep. Both the prediction model and the observed $k_{p}$ were based on data using the marker technique. It has been suggested by Van Soest (1994) and Cannas (2002) that sheep tend to have higher passage rates than cattle at similar physiological stages. The equations in the CNCPS sheep model (Cannas et al., 2004) were developed from a database where passage rate measurements on small (sheep and goat) and large (cattle and buffaloes) ruminants were pooled. Animal species was not significant in these predictions (Cannas and Van
Soest, 2000). Many of the rumen evacuation studies on sheep found in the literature used lignin as an indigestible marker; however, lignin has given faster estimates of $k_{p}$ than iNDF (Huhtanen and Kukkonen, 1995). The effect of markers would have been confounded with animal species and it was therefore decided not to proceed with data also trying to cover $k_{p}$ predictions in small ruminants. More research would be needed to clarify the difference between small and large ruminants on intake and passage rate of particulate matter, also with the aim of giving a more mechanistic explanation.

\section{Effect of Extrinsic Characteristics and Forage Type on Ruminal Particulate Matter Passage Rate}

Intake of NDF performed better as a predictor of $\mathrm{k}_{\mathrm{p}}$ of iNDF than DMI at all levels of regression in this data material. Lund (2002) and Rinne et al. (2002) observed faster $k_{p}$ of iNDF in dairy cows fed grass silages made from material harvested at later maturity stages. Despite increased $k_{\mathrm{p}}$, rumen pool size of fresh matter, DM, OM, NDF, and iNDF increased with progressing maturity of the grass silage in the study by Rinne et al. (2002). A biological reasoning for the better performance of NDFI than DMI as a predictor of particulate matter $k_{p}$ has been thoroughly discussed by Huhtanen et al. (2006) and further evaluated in the study by Krizsan et al. (2010). A proportionality factor of 1.6 was introduced in the Nordic dairy cow model Karoline to account for the higher $k_{p}$ of concentrates in relation to $k_{p}$ of forages (Danfær et al., 2006). In this meta-analysis, the faster $k_{p}$ of concentrate particles compared with forage particles was modeled by a positive coefficient for CProp (NDF) in the best multivariate model. Shaver 
et al. (1988) and Colucci et al. (1990) reported a generally faster $k_{p}$ of concentrate particles than of forage particles labeled with different markers when measured in early lactating dairy cows. Cannas and Van Soest (2000) used experiments where both forage and concentrate $\mathrm{k}_{\mathrm{p}}$ was measured at the same time and found a slope of 1.57 when regressing concentrate $\mathrm{k}_{\mathrm{p}}$ on forage $\mathrm{k}_{\mathrm{p}}$. Ahvenjärvi et al. (2010) observed that differences in retention time of rapeseed meal were consistent with the differences in forage retention time. This suggested that $\mathrm{k}_{\mathrm{p}}$ of concentrate could be predicted successfully from $k_{p}$ of forages. However, rumen conditions can be affected by diet type or amount of concentrate provided in the total diet. Robinson et al. (1987) and Stensig et al. (1998) reported that increased starch supplementation in the diet to dairy cows decreased ruminal particle passage rate. Using the marker technique, Colucci et al. (1990) observed that $\mathrm{k}_{\mathrm{p}}$ of both forage and concentrate

\section{Predicted kp NRC (\%/h)}

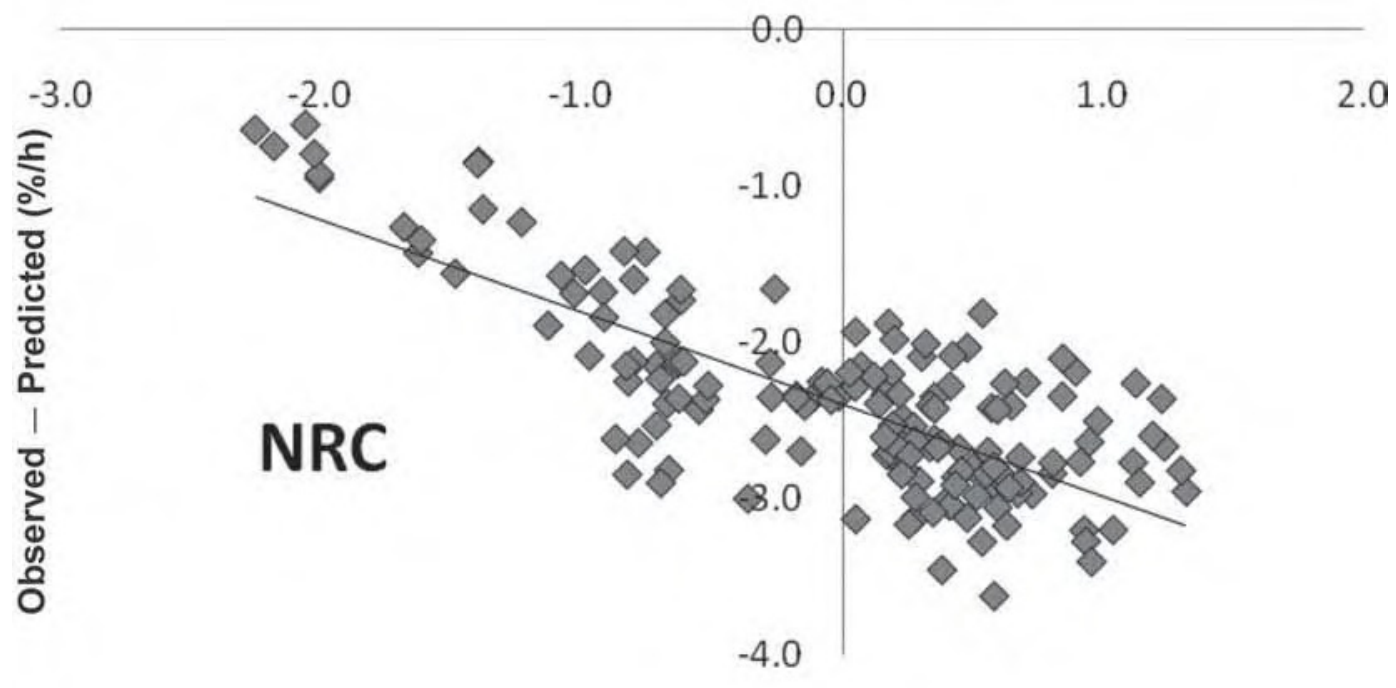

Predicted kp CNCPS (\%/h)

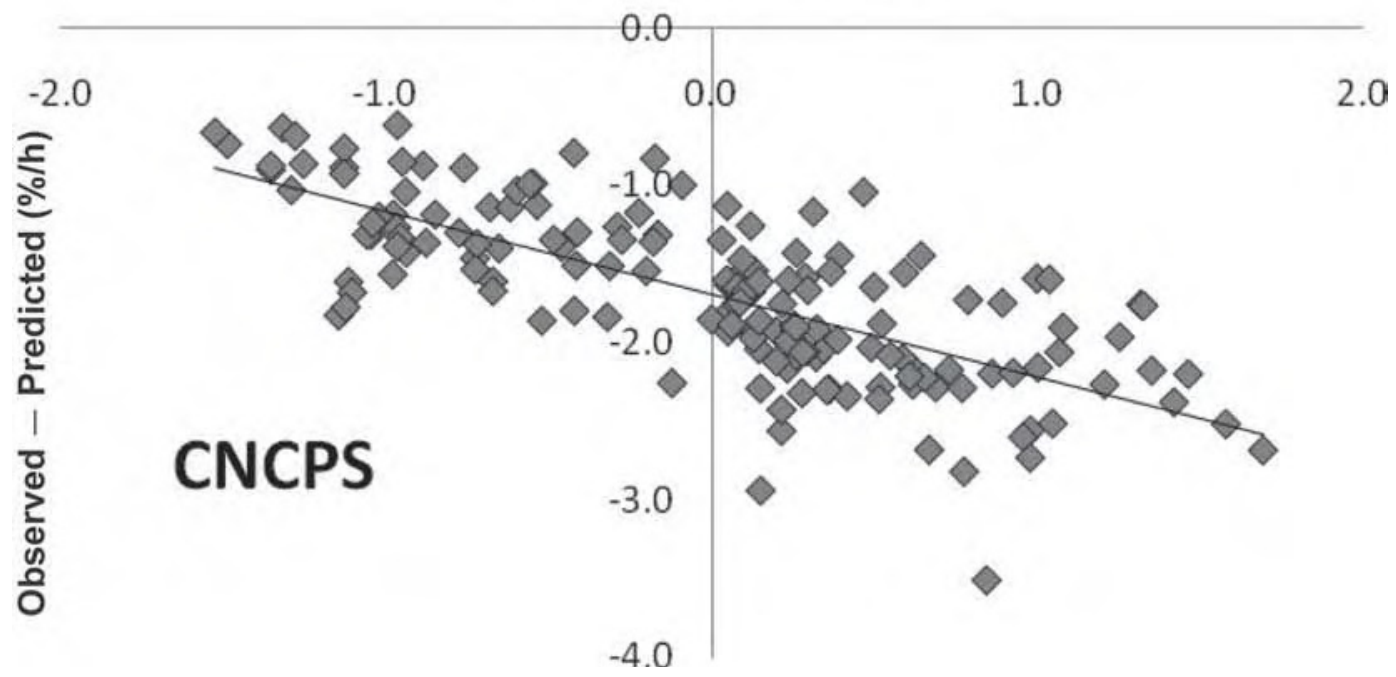

Figure 1. Plot of residuals (observed - predicted) versus predicted passage rate $\left(\mathrm{k}_{\mathrm{p}}\right)$ estimated according to the NRC and the Cornell Net Carbohydrate and Protein System (CNCPS). The regression lines in the graph represent the equations y $=-2.40( \pm 0.0287)-0.59( \pm 0.0372) \times$ predicted $\mathrm{k}_{\mathrm{p}}$ and $\mathrm{y}=-1.70( \pm 0.0270)-0.53( \pm 0.0373) \times$ predicted $\mathrm{k}_{\mathrm{p}}$ for the NRC and CNCPS models, respectively. Predicted $\mathrm{k}_{\mathrm{p}}$ for concentrate and forage feed from NRC and CNCPS equations were combined in an aggregated $\mathrm{k}_{\mathrm{p}}$ according to the flux/compartmental pool method. Predicted values were centered by subtracting the mean of all predicted values from each predicted value. 
particles decreased when the proportion of concentrate in the diet to dairy cows increased. The decrease in $\mathrm{k}_{\mathrm{p}}$ of forage particles was more pronounced at low levels of intake than at high levels of intake. This implies that the relationship between $k_{p}$ of concentrate and forage particles is not necessarily constant over the range of feed intake by cattle.

Passage rate can also be related to feed characteristics (intrinsic factors) other than particle size (e.g., functional specific gravity, proportion of leaf to stem, and factors associated with the resistance of cell walls to comminution; Huhtanen et al., 2006). The positive coefficient for iNDF:NDF in the best multivariate equations in this meta-analysis is related to the fact that $\mathrm{k}_{\mathrm{p}}$ increases when NDF potential digestibility decreases in feed particles. The iNDF:NDF ratio determined in feeds is related to the type of feed (generally higher iNDF:NDF ratio in concentrates than forages) or forage maturity. The results from this study suggested that, except for NDFI, other regressors describing diet composition were not relevant when an effect of forage type was included in the prediction of $\mathrm{k}_{\mathrm{p}}$.

The NRC (2001) developed separate $k_{p}$ equations for dry and wet forages, whereas one $\mathrm{k}_{\mathrm{p}}$ equation for all forages is used in CNCPS (Seo et al., 2006). Huhtanen and Jaakkola (1993) did not observe any differences between forage types on rumen evacuation-based $k_{p}$ when comparing grass hay and grass silage fed to growing cattle with different inclusions of concentrate supplementation. The statistical analysis in this study did not separate $\mathrm{k}_{\mathrm{p}}$ of hays from $\mathrm{k}_{\mathrm{p}}$ of grass silage-based diets $(P=0.95)$. The only forage types that were separated from the grass silage-based diets were fresh grass, mixes of alfalfa and corn silage, and dry or ensiled alfalfa as sole forage component. The slower $\mathrm{k}_{\mathrm{p}}$ with diets based on fresh grass is consistent with experimental data. The mean NDFI and $k_{p}$ of iNDF for 4 diets in the studies with cattle by Owens et al. $(2008 \mathrm{a}, \mathrm{b})$ were $7.89 \mathrm{~g} / \mathrm{kg}$ of BW and $1.45 \% / \mathrm{h}$, respectively. Further, the mean NDFI and $k_{p}$ of iNDF for 3 diets in the study with dairy cows by Sairanen et al. (2005) were $16.2 \mathrm{~g} / \mathrm{kg}$ of BW and $1.83 \% / h$, respectively. The faster estimated $k_{p}$ of diets based on alfalfa and corn silage than of diets based on grass silage in this meta-analysis is in agreement with the results of Lund (2002). The fastest $k_{p}$ of iNDF was reported for corn silage diets (2.66 and $2.87 \% / \mathrm{h}$ ); the alfalfa hay diet was in between (1.65 and $2.17 \% / \mathrm{h}$ ), and $\mathrm{k}_{\mathrm{p}}$ was lowest for grass hay (1.27 and $1.34 \% / \mathrm{h}$ ) when fed to dairy cows supplemented with concentrate or without any supplementation. Huhtanen et al. (2006) suggested that the effect of forage type on particulate matter $k_{p}$ would arise from differences in the consistency of the rumen raft. Further, there was no explanatory value of any extrinsic characteristics or diet chemical composition parameters except NDFI in prediction of $k_{p}$ of iNDF when an effect of forage type was included in the model.

\section{Linear or Curvilinear Predictions of Ruminal Particulate Matter Passage Rate}

In the present study, the curvilinear model using natural logarithmic transformed NDFI did not improve the model compared with the linear model. This is in contrast with the study of Cannas et al. (2003), who observed that a logarithmic model gave a better fit of the data than a linear model. The difference is because turnover time was used as the dependent variable, whereas passage rate was used in this study (i.e., the reciprocal of turnover time). The relationship between NDF intake and passage rate calculated from Cannas et al. (2003) turned out to be linear. Their model predicted shorter turnover times compared with our model, especially at high NDF intakes. In a direct comparison, based on the rumen evacuation technique, passage rate of ADL was $14 \%$ faster than that of iNDF (Huhtanen and Kukkonen, 1995). It is possible that some soluble phenolic compounds are released from particulate matter and flow in the rumen fluid phase, thereby lending to overestimates of fiber passage rate. Large lignin disappearance from grass samples incubated in nylon bags in the rumen supports this assertion (Huhtanen and Vanhatalo, 1997).

The predicted depression in NDF digestibility of $0.48 \% \mathrm{U} / \mathrm{kg}$ of increase in DMI compares well with the observed depression of $0.49 \% \mathrm{U}$ in the meta-analysis of data from digestibility trials with dairy cows (Huhtanen et al., 2009). In addition, the predicted ruminal NDF digestibility at the mean DMI of the data set (62.0\%) was close to the observed NDF digestibility (62.7\%). Total-tract digestibility of pdNDF in dairy cows was $75.4 \%$ on average (Nousiainen et al., 2009). Using the proportion of ruminal digestion of total NDF digestion (95\%) determined by omasal sampling technique (Huhtanen et al. 2010) gave a ruminal pdNDF digestibility of $71.3 \%$. Assuming a 1-compartment rumen model and $\mathrm{k}_{\mathrm{p}}$ calculated according to the NRC $(5.0 \% / \mathrm{h})$, digestion rate should be $12.4 \% / \mathrm{h}$ to reach $71.3 \%$ ruminal pdNDF digestibility and $8.8 \% / \mathrm{h}$ assuming a 2-compartment system (Allen and Mertens, 1988). Both of these values for digestion rate of pdNDF are unrealistically high for average dairy cow diets. Although these calculations are based on several assumptions, accurate predictions of both total NDF digestibility and depression in di- 
gestibility with increased DMI provide some evidence of the accuracy of passage kinetic models derived from rumen evacuation data.

\section{Evaluation of Passage Rate Models}

Prediction equations of $\mathrm{k}_{\mathrm{p}}$ in NRC and CNCPS are used in calculations of ruminal digestibility of carbohydrate and protein fractions in 1-compartment models (NRC, 2001; Fox et al., 2004). Generally, $\mathrm{k}_{\mathrm{p}}$ equations have been developed separately for forage and concentrate feed, and for predictions of ruminal liquid outflow. In all $k_{p}$ equations in NRC and CNCPS, intake of feed (i.e., either concentrate, forage, or total intake) is on a DM basis (NRC, 2001; Seo et al., 2006). Intake of NDF was a better explanatory variable in univariate as well as multivariate regressions compared with DMI in this meta-analysis. Further, the linear bias showed that the absolute difference between observed $k_{p}$ of iNDF and NRC and CNCPS predictions increased at higher values of $\mathrm{k}_{\mathrm{p}}$. However, DM- or NDF-based $\mathrm{k}_{\mathrm{p}}$ predictions alone cannot explain the observed negative mean biases (i.e., overestimation) on ruminal particulate matter $\mathrm{k}_{\mathrm{p}}$ predictions by the NRC and CNCPS models. Marker excretion curves from duodenal and fecal samples have indicated that passage of feed particles in ruminants is at least a 2-compartmental process. The ascending phase of duodenal marker excretion curve has been interpreted as selective retention of feed particles in an inescapable pool, and the concomitant descending phase of the curve as a compartment with mass action dilution turnover (Ellis et al., 1994). With the marker technique, ruminal passage rate of feed particles has usually been estimated from the descending phase of duodenal or fecal marker excretion curves. Compartmental mean retention time estimated from the descending phase of marker excretion curves has been markedly shorter than the proportion of fore-stomachs to total mean retention time determined from lignin or iNDF recovery in slaughter studies (Paloheimo and Mäkelä, 1959; Huhtanen and Ahvenjärvi, 2008). The rumen evacuation technique is an alternative to measuring rumen contents by slaughter. The technique is based on first-order kinetics and a 1-compartment model; passage kinetics of the reticulo-rumen are determined for the whole diet, and it is not possible to separate $k_{p}$ of forages and concentrate particles.

The equations in NRC and CNCPS have been developed based on large sets of empirical data using rare earths alone (NRC) or with data of Cr-mordanted fiber as a $k_{p}$ marker (CNCPS). Longer retention times when Cr-mordanted fiber was compared with Yb-labeled fiber (Beauchemin and Buchanan-Smith, 1989; Huhtanen and Kukkonen, 1995) suggest that marker type influences estimated values. Cannas and Van Soest (2000) presented a significant effect of marker when comparing rare earths with $\mathrm{Cr}$ in $\mathrm{k}_{\mathrm{p}}$ regressions based on DMI but not NDFI. Passage rate equations of forages and concentrates in CNCPS were not corrected for the effect of marker (Seo et al., 2006). The NRC (2001) did not include data of Cr-mordanted feeds because no independent variables could be related to $\mathrm{k}_{\mathrm{p}}$ of concentrate particles when these data were included. Particle density or level of $\mathrm{Cr}$ mordanted to the fiber (Lirette and Milligan, 1989), labeling method of rare earths (Ellis et al., 1994), and particle size or particle distribution of the mordanted feed (Bruining and Bosch, 1992) are factors that in addition to relative differences due to animal and feed characteristics have affected the passage rate or retention time estimates.

This analysis suggests that rumen residence time of feed particles is markedly longer than the $\mathrm{k}_{\mathrm{p}}$ values predicted in the current feed protein evaluation systems (e.g., NRC and CNCPS). Using the current passage rate estimates would increase calculated values of ruminal protein degradability. The results of this metaanalysis suggest that differences in omasal feed protein flow are smaller than predicted by the NRC (2001) system (Broderick et al., 2010). Similarly, the small effects of ruminal protein degradability on milk protein yield and efficiency of $\mathrm{N}$ utilization in milk production studies (Huhtanen and Hristov, 2009) suggest that the true differences in ruminal protein degradability could be smaller than those in the tabulated values.

\section{CONCLUSIONS}

In agreement with previous conclusions, intake of NDF was the best single predictor of ruminal particulate matter passage rate in this study. The positive coefficient for dietary proportion of concentrate on NDF basis is related to the faster $k_{p}$ of concentrate particles compared with forage particles. An increased ratio of iNDF:NDF in the diet indicated that $\mathrm{k}_{\mathrm{p}}$ increases when NDF potential digestibility decreases. The iNDF:NDF ratio in feeds is related to the type of feed (concentrate vs. forage or forage type) or forage maturity. Further, when forage type was accounted for in the prediction of $\mathrm{k}_{\mathrm{p}}$ no other independent variables in addition to intake of NDF improved the model. Considering different ruminal passage rates between forage types, future feed evaluations for ruminants could contribute to more precise estimates of ruminal digestibility of carbohydrate and protein fractions. However, more research is needed to confirm the importance of relative forage differences in a rumen model and to separate animal effects from feed factors in predictions of ruminal particulate matter $k_{p}$. The $k_{p}$ estimates derived from rumen evacuation 
data were lower than predictions of ruminal particulate matter $\mathrm{k}_{\mathrm{p}}$ from NRC and the CNCPS. Rumen evacuation-derived $\mathrm{k}_{\mathrm{p}}$ estimates include the retention time in the large particle pool, whereas $\mathrm{k}_{\mathrm{p}}$ estimated from marker kinetics are derived from the descending phase of the marker curve that represents retention time in the small particle compartment.

\section{ACKNOWLEDGMENTS}

J. Bertilsson, T. Eriksson, R. Spörndly (Swedish University of Agricultural Sciences, Uppsala, Sweden), K. Kuoppala (MTT Agrifood Research Finland, Animal Production Research, Jokioinen, Finland), S. K. Nes, E. Prestløkken, and H. Volden (Norwegian University of Life Sciences, Ås, Norway) have complemented published data or contributed with unpublished data.

\section{REFERENCES}

Ahvenjärvi, S., M. Rinne, T. Heikkilä, and P. Huhtanen. 2010. The effect of a diet and intrinsic characteristics of feed particles on passage kinetics in dairy cows. Pages 162-165 in Proc. 1st Nordic Feed Science Conference, Uppsala. SLU Repro, Uppsala, Sweden.

Allen, M. S., and D. R. Mertens. 1988. Evaluating constraints on fiber digestion by rumen microbes. J. Nutr. 118:261-270.

Beauchemin, K. A., and J. G. Buchanan-Smith. 1989. Evaluation of markers, sampling sites and models for estimating rates of passage of silage and hay in dairy cows. Anim. Feed Sci. Technol. $27: 59-75$.

Broderick, G. A., P. Huhtanen, S. Ahvenjärvi, S. M. Reynal, and K. J. Shingfield. 2010. Quantifying ruminal nitrogen metabolism using the omasal sampling technique in cattle- A meta-analysis. J. Dairy Sci. 93:3216-3230.

Bruining, M., and M. W. Bosch. 1992. Ruminal passage rate as affected by CrNDF particle size. Anim. Feed Sci. Technol. 37:193-200.

Cannas, A. 2002. Feeding of lactating ewes. Pages 123-166 in Dairy Sheep Feeding and Nutrition. 2nd ed. G. Pulina, ed. Avenue Media, Bologna, Italy.

Cannas, A., L. O. Tedeschi, D. G. Fox, A. N. Pell, and P. J. Van Soest. 2004. A mechanistic model for predicting the nutrient requirements and feed biological values for sheep. J. Anim. Sci. 82:149-169.

Cannas, A., and P. J. Van Soest. 2000. Simple allometric models to predict rumen feed passage rate in domestic ruminants. Pages 49-62 in Modelling Nutrient Utilization in Farm Animals. J. P. McNamara, J. France, and D. E. Beever, ed. CAB International, Wallingford, UK.

Cannas, A., P. J. Van Soest, and A. N. Pell. 2003. Use of animal and dietary information to predict rumen turnover. Anim. Feed Sci. Technol. 106:95-117.

Colucci, P. E., G. K. Macleod, W. L. Grovum, I. McMillan, and D. J. Barney. 1990. Digesta kinetics in sheep and cattle fed diets with different forage to concentrate ratios at high and low intakes. J. Dairy Sci. 73:2143-2156.

Dado, R. G., and M. S. Allen. 1995. Intake limitations, feeding behavior, and rumen function of cows challenged with rumen fill from dietary fiber or inert bulk. J. Dairy Sci. 78:118-133.

Danfær, A., P. Huhtanen, P. Udén, J. Sveinbjörnsson, and H. Volden. 2006. The Nordic dairy cow model, Karoline - Description. Pages 383-406 in Nutrient Digestion and Utilization in Farm Animals: Modelling Approaches. E. Kebreab, J. Dijkstra, A. Bannink, J. Gerrits, and J. France, ed. CAB International, Wallingford, UK.

Ellis, W. C., J. H. Matis, T. M. Hill, and M. R. Murphy. 1994. Methodology for estimating digestion and passage kinetics of forages. Pages $682-756$ in Forage Quality, Evaluation, and Utilization. G.
C. Fahey, Jr., M. Collins, D. R. Mertens, and L. E. Moser, ed. American Society of Agronomy, Madison. WI.

Fox, D. G., L. O. Tedeschi, T. P. Tylutki, J. B. Russell, M. E. Van Amburgh, L. E. Chase, A. N. Pell, and T. R. Overton. 2004. The Cornell Net Carbohydrate and Protein System model for evaluating herd nutrition and nutrient excretion. Anim. Feed Sci. Technol. 112:29-78.

Huhtanen, P., and S. Ahvenjärvi. 2008. Prediction of rumen residence time using markers or rumen evacuation and slaughter data. Can. J. Anim. Sci. 88:733. (Abstr.)

Huhtanen, P., S. Ahvenjärvi, G. A. Broderick, S. M. Reynal, and K. J. Shingfield. 2010. Quantifying ruminal digestion of organic matter and neutral detergent fiber using the omasal sampling technique in cattle - A meta-analysis. J. Dairy Sci. 93:3203-3215.

Huhtanen, P., S. Ahvenjärvi, M. R. Weisbjerg, and P. Nørgaard. 2006. Digestion and passage of fibre in ruminants. Pages 87-135 in Ruminant Physiology: Digestion, Metabolism and Impact of Nutrition in Gene Impression, Immunology and Stress. K. Sejrsen, T. Hvelplund, M. O. Nielsen, ed. Wageningen Academic Publishers, Wageningen, the Netherlands.

Huhtanen, P., U. Asikainen, M. Arkkila, and S. Jaakkola. 2007. Cell wall digestion and passage kinetics estimated by marker and in situ methods or by rumen evacuations in cattle fed hay 2 or 18 times daily. Anim. Feed Sci. Technol. 133:206-227.

Huhtanen, P., and A. N. Hristov. 2009. A meta-analysis of the effects of dietary protein concentration and degradability on milk protein yield and milk $\mathrm{N}$ efficiency in dairy cows. J. Dairy Sci. 92:3222-3232.

Huhtanen, P., and S. Jaakkola. 1993. The effects of forage preservation method and proportion of concentrate on digestion of cell wall carbohydrates and rumen digesta pool size in cattle. Grass Forage Sci. 48:155-165.

Huhtanen, P., and U. Kukkonen. 1995. Comparison of methods, markers, sampling sites and models for estimating digesta passage kinetics in cattle fed at two levels of intake. Anim. Feed Sci. Technol. 52:141-158.

Huhtanen, P., M. Rinne, and J. Nousiainen. 2009. A meta-analysis of feed digestion in dairy cows. 2 . The effects of feeding level and diet composition on digestibility. J. Dairy Sci. 92:5031-5042.

Huhtanen, P., and A. Vanhatalo. 1997. Ruminal and total plant cellwall digestibility estimated by a combined in situ method utilizing mathematical models. Br. J. Nutr. 78:583-598.

Krizsan, S. J., S. Ahvenjärvi, H. Volden, and P. Huhtanen. 2010. Relationship between passage rate and extrinsic diet characteristics derived from rumen evacuation studies performed with dairy cows. Pages 191-200 in Modelling Nutrient Digestion and Utilization in Farm Animals. D. Sauvant, J. van Milgen, P. Faverdin, and N. Friggens, ed. Wageningen Academic Publishers, Wageningen, the Netherlands.

Kuoppala, K., S. Ahvenjärvi, M. Rinne, and A. Vanhatalo. 2009. Effects of feeding grass or red clover silage cut at two maturity stages in dairy cows. 2. Dry matter intake and cell wall digestion kinetics. J. Dairy Sci. 92:5634-5644.

Kuoppala, K., M. Rinne, S. Ahvenjärvi, J. Nousiainen, and P. Huhtanen. 2010. The effect of harvesting strategy of grass silage on digestion and nutrient supply in dairy cows. J. Dairy Sci. 93:3253-3263.

Lirette, A., and L. P. Milligan. 1989. A quantitative model of reticulorumen particle degradation and passage. Br. J. Nutr. 62:465479

Littell, R. C., G. A. Milliken, W. W. Stroup, and R. D. Wolfinger. 1996. SAS System for Mixed Models. SAS Inst., Inc., Cary, NC.

Lund, P. 2002. The effect of forage type on passage kinetics and digestibility of fibre in dairy cows. PhD Thesis. The Royal Veterinary and Agricultural University, Copenhagen, Denmark.

Nousiainen, J., M. Rinne, and P. Huhtanen. 2009. A meta-analysis of feed digestion in dairy cows. 1 . The effects of forage and concentrate factors on total diet digestibility. J. Dairy Sci. 92:50195030 .

NRC. 2001. Nutrient Requirements of Dairy Cattle. 7th rev. ed. Natl. Acad. Press, Washington, DC. 
Owens, D., M. McGee, and T. Boland. 2008a. Effect of grass regrowth interval on intake, rumen digestion and nutrient flow to the omasum in beef cattle. Anim. Feed Sci. Technol. 146:21-41.

Owens, D., M. McGee, and T. Boland. 2008b. Intake, rumen fermentation, degradability and digestion kinetics in beef cattle offered autumn grass herbage differing in regrowth interval. Grass Forage Sci. 63:369-379.

Paloheimo, L., and A. Mäkelä. 1959. Further studies on the retention time of food in the digestive tract of cows. Acta Agralia Fenniae 94:15-39.

Poppi, D. P., W. C. Ellis, J. H. Matis, and C. E. Lascano. 2001. Marker concentration patterns of labelled leaf and stem particles in the rumen of cattle grazing bermuda grass (Cynodon dactylon) analysed by reference to a raft model. Br. J. Nutr. 85:553-563.

Rinne, M., P. Huhtanen, and S. Jaakkola. 2002. Digestive processes of dairy cows fed silages harvested at four stages of maturity. J. Anim. Sci. 80:1986-1998.

Robinson, P. H., S. Tamminga, and A. M. VanVuuren. 1987. Influence of declining level of feed intake and varying the proportion of starch in the concentrate on rumen ingesta quantity, composition and kinetics of ingesta turnover in dairy cows. Livest. Prod. Sci. $17: 37-62$.

Sairanen, A., H. Khalili, J. I. Nousiainen, S. Ahvenjärvi, and P. Huhtanen. 2005. The effect of concentrate supplementation on nutrient flow to the omasum in dairy cows receiving freshly cut grass. J. Dairy Sci. 88:1443-1453.

Sauvant, D., P. Schmidely, J. J. Daudin, and N. R. St-Pierre. 2008 Meta-analyses of experimental data in animal nutrition. Animal 2:1203-1214.

Seo, S., L. O. Tedeschi, C. Lanzas, C. G. Schwab, and D. G. Fox. 2006 Development and evaluation of empirical equations to predict feed passage rate in cattle. Anim. Feed Sci. Technol. 128:67-83.

Shaver, R. D., L. D. Satter, and N. A. Jorgensen. 1988. Impact of forage fiber content on digestion and digesta passage in lactating dairy cows. J. Dairy Sci. 71:1556-1565.

St-Pierre, N. R. 2001. Integrating quantitative findings from multiple studies using mixed model methodology. J. Dairy Sci. 84:741755

St-Pierre, N. R. 2003. Reassessment of biases in predicted nitrogen flows to the duodenum by NRC 2001. J. Dairy Sci. 86:344-350.

Stensig, T., M. R. Weisbjerg, and T. Hvelplund. 1998. Digestion and passage kinetics of fibre in dairy cows as affected by the proportion of wheat starch or sucrose in the diet. Acta Agric. Scand. 48:129-140.

Van Soest, P. J. 1994. Nutritional Ecology of the Ruminant. 2nd ed Cornell Univ. Press, Ithaca, NY.

Walz, L. S., W. C. Ellis, T. W. White, J. H. Matis, H. G. Bateman, C. C. Williams, J. M. Fernandez, and L. R. Gentry. 2004. Flow paths of plant tissue residues and digesta through gastrointestinal segments in Spanish goats and methodological considerations. J. Anim. Sci. 82:508-520.

\section{APPENDIX}

\section{References Used for the Meta-Analysis}

Ahvenjärvi, S., E. Joki-Tokola, A. Vanhatalo, S. Jaakkola, and P. Huhtanen. 2006. Effects of replacing grass silage with barley silage in dairy cow diets. J. Dairy Sci. 89:1678-1687.

Ahvenjärvi, S., M. Korhonen, A. Vanhatalo, and P. Huhtanen. Digestion and passage kinetics of fiber in dairy cows fed primary and secondary growth grass silage supplemented with 2 levels of concentrate. Unpublished data.

Ahvenjärvi, S., A. Vanhatalo, and P. Huhtanen. Ruminal metabolism of silage soluble $\mathrm{N}$ fractions. Unpublished data.

Ahvenjärvi, S., M. Rinne, T. Heikkilä, and P. Huhtanen. 2010. The effect of a diet and intrinsic characteristics of feed particles on passage kinetics in dairy cows. Pages 162-165 in Proc. 1st Nordic Feed Science Conference, Uppsala. SLU Repro, Uppsala, Sweden.
Bertilsson, J. 2005. Feeding mixed grass-clover silages with elevated sugar contents to dairy cows. Page 227 in Proc. XIVth Int. Silage Conf., Belfast, Northern Ireland. R. S. Park and M. D. Stronge, ed. Wageningen Academic Publishers, Wageningen, The Netherlands.

Bosch, M. W., and M. Bruining. 1995. Passage rate and total clearance rate from the rumen of cows fed on grass silages differing in cellwall content. Br. J. Nutr. 73:41-49.

Chow, L. O., V. S. Baron, R. Corbett, and M. Oba. 2008. Effects of planting date on fiber digestibility of whole-crop barley and productivity of lactating dairy cows. J. Dairy Sci. 91:1534-1543.

Dado, R. G., and M. S. Allen. 1995. Intake limitations, feeding behavior, and rumen function of cows challenged with rumen fill from dietary fiber or inert bulk. J. Dairy Sci. 78:118-133.

Eriksson, T., M. Murphy, P. Ciszuk, and E. Burstedt. 2004. Nitrogen balance, microbial protein production, and milk production in dairy cows fed fodder beets and potatoes, or barley. J. Dairy Sci. $87: 1057-1070$

Eriksson, T., and N. Nilsdotter-Linde. Milk production, nitrogen balance and digestion in dairy cows fed grass-legume silage with either birdsfoot trefoil or white clover. Unpublished data.

Gasa, J., K. Holtenius, J. D. Suttons, M. S. Dhanoa, and D. J. Napper. 1991. Rumen fill and digesta kinetics in lactating Friesian cows given 2 levels of concentrates with 2 types of grass silage ad lib. Br. J. Nutr. 66:381-398.

Harvatine, D. I., J. L. Firkins, and M. L. Eastridge. 2002. Whole linted cottonseed as a forage substitute fed with ground or steam-flaked corn: Digestibility and performance. J. Dairy Sci. 85:1976-1987.

Harvatine, D. I., J. E. Winkler, M. Devant-Guille, J. L. Firkins, N. R. St-Pierre, B. S. Oldick, and M. L. Eastridge. 2002. Whole linted cottonseed as a forage substitute: Fiber effectiveness and digestion kinetics. J. Dairy Sci. 85: 1988-1999.

Huhtanen, P., U. Asikainen, M. Arkkila, and S. Jaakkola. 2007. Cell wall digestion and passage kinetics estimated by marker and in situ methods or by rumen evacuations in cattle fed hay 2 or 18 times daily. Anim. Feed Sci. Technol. 133:206-227.

Huhtanen, P., and S. Jaakkola. 1993. The effects of forage preservation method and proportion of concentrate on digestion of cell wall carbohydrates and rumen digesta pool size in cattle. Grass Forage Sci. 48:155-165.

Huhtanen, P., and H. Khalili. 1991. Sucrose supplements in cattle given grass silage-based diet. 3. Rumen pool size and digestion kinetics. Anim. Feed Sci. Technol. 33: 275-287.

Huhtanen, P., and U. Kukkonen. 1995. Comparison of methods, markers, sampling sites and models for estimating digesta passage kinetics in cattle fed at 2 levels of intake. Anim. Feed Sci. Technol. $52: 141-158$.

Karp, V. 2005. The effect of whole crop pea-barley silage on ruminal fermentation, microbial synthesis, digestibility, and intake in dairy cows. MS Thesis. Helsinki Univ., Finland.

Khalili, H., and P. Huhtanen. 2002. Effect of casein infusion in the rumen, duodenum or both sites on factors affecting forage intake and performance of dairy cows fed red clover grass silage. J. Dairy Sci. 85:909-918

Kuoppala K., S. Ahvenjärvi, M. Rinne, and A. Vanhatalo. 2009. Effects of feeding grass or red clover silage cut at 2 maturity stages in dairy cows. 2. Dry matter intake and cell wall digestion kinetics. J. Dairy Sci. 92:5634-5644.

Kuoppala, K., M. Rinne, S. Ahvenjärvi, J. Nousiainen, and P. Huhtanen. 2010. The effect of harvesting strategy of grass silage on digestion and nutrient supply in dairy cows. J. Dairy Sci. 93:32533263

Kuusonen, U. 2001. Red clover and oriental goat's rue fed solely or as a mixture with meadow fescue silage to the dairy cows. MS Thesis. Helsinki Univ., Finland.

Lund, P., 2002. The effect of forage type on passage kinetics and digestibility of fiber in dairy cows. Ph.D. Thesis. The Royal Veterinary and Agricultural Univ., Copenhagen, Denmark.

Minde, A. and Rygh, A. J., 1997. Metoder for å bestemme nedbrytningshastighet, passasjehastighet og vomfordøyelighet av NDF hos melkeku [Methods for determination of rates of degradation and passage, and ruminal digestibility of neutral detergent fiber 
in dairy cows]. MS Thesis. Norwegian Univ. of Life Sciences, Ås, Norway.

Murphy, M., M. Åkerlind, and K. Holtenius. 2000. Rumen fermentation in lactating cows selected for milk fat content fed 2 forage to concentrate ratios with hay or silage. J. Dairy Sci. 83:756-764.

Nes, S. K., S. J. Krizsan, L. Norell, and H. Volden. Ruminal particulate matter passage rate in lactating cows fed grass silage of different maturity at 2 levels of concentrate supplementation. Unpublished data.

Oba, M., and M. S. Allen. 2000. Effect of brown midrib 3 mutation in corn silage on productivity of dairy cows fed 2 levels of dietary neutral detergent fiber: 1 . Feeding behavior and nutrient utilization. J. Dairy Sci. 83:1333-1341.

Oba, M., and M. S. Allen. 2000. Effects of brown midrib 3 mutation in corn silage on productivity of dairy cows fed 2 concentrations of dietary neutral detergent fiber: 2. Chewing activities. J. Dairy Sci. 83:1342-1349.

Oba, M., and M. S. Allen. 2000. Effect of brown midrib 3 mutation in corn silage on productivity of dairy cows fed 2 levels of dietary NDF: 3. Digestibility and microbial efficiency. J. Dairy Sci. 83:1350-1358.

Oba, M., and M. S. Allen. 2003. Effects of corn grain conservation method on feeding behavior and productivity of lactating dairy cows at 2 dietary starch concentrations. J. Dairy Sci. 86:174-183.

Oba, M., and M. S. Allen. 2003. Effects of corn grain conservation method on ruminal digestion kinetics for lactating dairy cows at 2 dietary starch concentrations. J. Dairy Sci. 86:184-194.

Oba, M., and M. S. Allen. 2003. Effects of diet fermentability on efficiency of microbial nitrogen production in lactating dairy cows. J. Dairy Sci. 86:195-207.

Oosting, S. J., P. J. M. Vlemmix, and J. Van Bruchem. 1994. Effect of ammonia treatment of wheat straw with or without supplementation of potato protein on intake, digestion and kinetics of comminution rumen degradation and passage in steers. Br. J. Nutr. 72:147-165.

Owens, D., M. McGee, and T. Boland. 2008a. Effect of grass regrowth interval on intake, rumen digestion and nutrient flow to the omasum in beef cattle. Anim. Feed Sci. Technol. 146:21-41.

Owens, D., M. McGee, and T. Boland. 2008b. Intake, rumen fermentation, degradability and digestion kinetics in beef cattle offered autumn grass herbage differing in regrowth interval. Grass Forage Sci. 63:369-379.

Prestløkken, E., A. T. Randby, and T. Garmo. Effect of harvesting time and wilting on feed intake and production by dairy cows. Unpublished data.

Rinne, M., P. Huhtanen, and S. Jaakkola. 1997. Grass maturity effects on cattle fed silage-based diets. 2. Cell wall digestibility, digestion and passage kinetics. Anim. Feed Sci. Technol. 67:19-35.

Rinne, M., P. Huhtanen, and S. Jaakkola. 2002. Digestive processes of dairy cows fed silages harvested at 4 stages of grass maturity. J. Anim. Sci. 80:1986-1998.

Robinson, P. H., S. Tamminga, and A. M. VanVuuren. 1986. Influence of declining level of feed intake and varying the proportion of starch in the concentrate on rumen fermentation in dairy cows. Livest. Prod. Sci. 15:173-189.

Robinson, P. H., S. Tamminga, and A. M. VanVuuren. 1987. Influence of declining level of feed intake and varying the proportion of starch in the concentrate on milk production and whole tract digestibility in dairy cows. Livest. Prod. Sci. 17:19-35.

Robinson, P. H., S. Tamminga, and A. M. VanVuuren. 1987. Influence of declining level of feed intake and varying the proportion of starch in the concentrate on rumen ingesta quantity, composition and kinetics of ingesta turnover in dairy cows. Livest. Prod. Sci. $17: 37-62$.

Sairanen, A., H. Khalili, J. I. Nousiainen, S. Ahvenjärvi, and P. Huhtanen. 2005. The effect of concentrate supplementation on nutrient flow to the omasum in dairy cows receiving freshly cut grass. J. Dairy Sci. 88:1443-1453.

Spörndly, R., and T. Eriksson. The impact of the physical structure of forage fiber on rumen metabolism, feed intake and milk production in dairy cows. Unpublished data.

Stensig, T., and P. H. Robinson. 1997. Digestion and passage kinetics of forage fiber in dairy cows as affected by fiber-free concentrate in the diet. J. Dairy Sci. 80:1339-1352.

Stensig, T., M. R. Weisbjerg, and T. Hvelplund. 1998. Digestion and passage kinetics of fiber in dairy cows as affected by the proportion of wheat starch or sucrose in the diet. Acta Agric. Scand., Anim. Sci. 48:129-140.

Tamminga, S., P. H. Robinson, M. Vogt, and H. Boer. 1989. Rumen ingesta kinetics of cell wall components in dairy cows. Anim. Feed Sci. Technol. 25:89-98.

Taylor, C. C., and M. S. Allen. 2005. Corn grain endosperm type and brown midrib 3 corn silage: Feeding behavior and milk yield of lactating cows. J. Dairy Sci. 88:1425-1433.

Taylor, C. C., and M. S. Allen. 2005. Corn grain endosperm type and brown midrib 3 corn silage: Site of digestion and ruminal kinetics in lactating cows. J. Dairy Sci. 88:1413-1424.

Taylor, C. C., and M. S. Allen. 2005. Corn grain endosperm type and brown midrib 3 corn silage: Ruminal fermentation and N partitioning in lactating cows. J. Dairy Sci. 88:1434-1442.

Tesfa, A. T. 1993. Effects of rape-seed oil supplementation on digestion, microbial protein synthesis and duodenal microbial amino acid composition in ruminants. 41:313-328.

Voelker, J. A., G. M. Burato, and M. S. Allen. 2002. Effects of pretrial milk yield on responses of feed intake, digestion, and production to dietary forage concentration. J. Dairy Sci. 85:2650-2661.

Voelker, J. A., and M. S. Allen. 2003. Pelleted beet pulp substituted for high-moisture corn: 1. Effects on feed intake, chewing behavior, and milk production in lactating dairy cows. J. Dairy Sci $86: 3542-3552$.

Voelker, J. A., and M. S. Allen. 2003. Pelleted beet pulp substituted for high-moisture corn: 2. Effects on digestion and rumen digestion kinetics in lactating dairy cows. J. Dairy Sci. 86:3553-3561.

Voelker, J. A., and M. S. Allen. 2003. Pelleted beet pulp substituted for high-moisture corn: 3. Effects on ruminal fermentation, $\mathrm{pH}$, and microbial protein efficiency in lactating dairy cows. J. Dairy Sci. 86:3562-3570.

Voelker Linton J. A., and M. S. Allen. 2007. Nutrient demand affects ruminal digestion responses to a change in dietary forage concentration. J. Dairy Sci. 90:4770-4779.

Voelker Linton, J. A., and M. S. Allen. 2008. Nutrient demand interacts with forage family to affect intake and digestion responses in dairy cows. J. Dairy Sci. 91: 2694-2701. 